\title{
Annual and Daily Meteorological Cycles at High Altitude on a Tropical Mountain
}

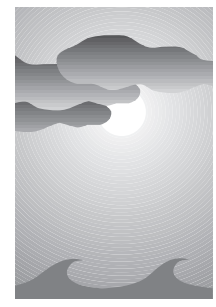

\author{
Douglas R. Hardy, Mathias Vuille, Carsten Braun, \\ Frank Keimig, and Raymond S. Bradley \\ Department of Geosciences, University of Massachusetts Amherst, Amherst, Massachusetts
}

\begin{abstract}
An automated weather station was installed in October 1996 at the summit of Nevado Sajama, located in the western Andean Cordillera of Bolivia ( $\left.6542 \mathrm{~m}, 18^{\circ} 06^{\prime} \mathrm{S}, 68^{\circ} 53^{\prime} \mathrm{W}\right)$. Meteorological conditions on the mountain are being observed to improve the calibration of geochemical variations within tropical ice cores. This article documents the design and operation of the station and presents a discussion of measurements made through the first annual cycle. Variables analyzed include pressure, incoming solar radiation, air temperature, humidity, wind, and snow accumulation. Large diurnal fluctuations were recorded in most variables, which is not unexpected given the location at $18^{\circ} \mathrm{S}$; the data also reveal substantial day-to-day variability and rapid seasonal changes in weather and circulation. As a result, snowfall events and periods of evaporation are more episodic in nature than previously believed. Measurement of atmospheric conditions during and between snowfall events will therefore greatly facilitate the interpretation of geochemical variations in each resultant snowpack layer.
\end{abstract}

\section{Introduction}

Abundant evidence indicates that dramatic changes in climate and in the hydrological cycle are occurring in the Tropics. Freezing-level height, for example, rose $\sim 110 \mathrm{~m}$ from 1970 to the late 1980 s, which appears to be linked to an increase in sea surface temperature (Diaz and Graham 1996). Ice caps and glaciers have been rapidly melting and retreating in South America (Francou and Ribstein 1995; Jordan 1995; Thompson et al. 1993; Schubert 1992), East Africa (Hastenrath and Kruss 1992; Kaser and Noggler 1996), and in southeast Asia (Peterson and Peterson 1996). The cause of these changes is not clear, although general circulation model experiments suggest that high elevations in the Tropics may be particularly vulnerable to greenhouse gas-induced warming (Mitchell et al.

Corresponding author address: Douglas R. Hardy, Dept. of Geosciences, Morrill Science Center, University of Massachusetts, Amherst, Amherst, MA 01003-5820.

E-mail: dhardy@geo.umass.edu

In final form 23 April 1998.

C1998 American Meteorological Society
1990). The significance of these observed changes can be appreciated only in the context of fluctuations over a longer time frame, yet instrumental records are generally short. Consequently, long-term, high-resolution proxy records from the Tropics are an essential prerequisite to placing the contemporary climate conditions in perspective. High-elevation ice cores can provide such proxy climate information.

Ice cores from low latitudes generally have high accumulation rates, providing high-resolution records of atmospheric processes involved in moisture transport to the site (e.g., Grootes et al. 1989) and of prevailing air masses and atmospheric circulation in the past (e.g., Mayewski et al. 1993). Among the important proxies for paleoclimatic reconstruction from tropical ice core records are microparticles (dust), concentration of chemical species [e.g., chloride $\left(\mathrm{Cl}^{-}\right)$, nitrate $\left(\mathrm{NO}_{3}^{-}\right)$, and sulfate $\left(\mathrm{SO}_{4}{ }^{2-}\right)$ ], precipitation amount (water equivalence), and stable isotope content $\left(\delta^{18} \mathrm{O}, \delta \mathrm{D}\right)$ (Thompson et al. 1984; Thompson et al. 1985; Thompson et al. 1995; Thompson 1995). In the past, the climatic information required for interpreting geochemical variations in climatic terms (calibration models) has not been available; as a re- 
sult, the climatic signal represented by the variability of some constituents in tropical ice cores (e.g., nitrate) is poorly understood (Thompson et al. 1995). For example, models of stable isotope content typically relate $\delta \mathrm{O}^{18}$ and $\delta \mathrm{D}$ to air temperature, but such relationships are especially questionable at low-latitude sites (Rozanski and Araguás 1995). Also important are the climatic conditions at the moisture source, and fractionation processes during moisture transport and following deposition (e.g., Grootes et al. 1989). Furthermore, there is a strong relationship in the Tropics between the stable isotope composition $\left(\delta \mathrm{O}^{18}, \delta \mathrm{D}\right)$ and the precipitation amount (e.g., Aravena et al. 1989; Rozanski and Araguás 1995).

To improve the calibration of geochemical variations within tropical ice cores, we installed satellitelinked, automated weather stations (AWS) at the summits of two Andean mountains in Bolivia (Fig. 1). Nevado Sajama is an ice-capped volcano $(6542 \mathrm{~m}$, $\left.18^{\circ} 06^{\prime} \mathrm{S}, 68^{\circ} 53^{\prime} \mathrm{W}\right)$, where we are collaborating with L.G. Thompson (Ohio State University), whose group recovered two ice cores to bedrock from the summit in June and July of 1997. The other station is located near the summit of Nevado Illimani in the Cordillera Real (6265 m, 16 $\left.39^{\prime} \mathrm{S}, 67^{\circ} 47^{\prime} \mathrm{W}\right)$, where another drilling campaign is anticipated within the next few years.

The objective of our ice-core calibration effort is to better understand the atmospheric signals in the snow, by developing associations between properties of individual snowpack strata and both the airmass and postdepositional history of that snow, at a finescale vertical resolution. The Sajama and Illimani stations are both designed to measure all critical meteorologi-

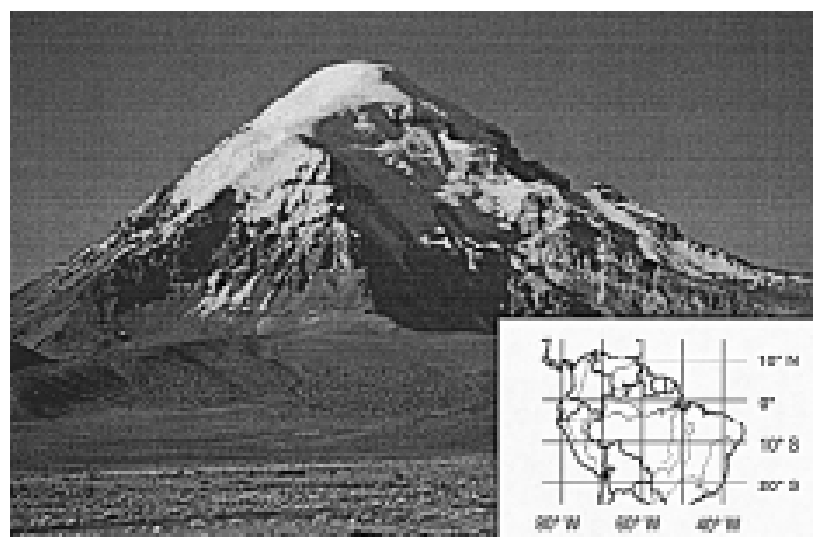

FIG. 1. Nevado Sajama, viewed from the south $\left(6542 \mathrm{~m}, 18^{\circ} 06^{\prime}\right.$ $\left.\mathrm{S}, 68^{\circ} 53^{\prime} \mathrm{W}\right)$. Inset shows northern South America, with location of Sajama (triangle) and Nevado Illimani (crosshair; $6265 \mathrm{~m}$, $\left.16^{\circ} 47^{\prime} \mathrm{W}\right)$. Rivers are shown in gray. cal variables. The analysis of station data is closely tied to the results of annual snowpack studies carried out in the vicinity of the automatic weather stations. Individual stratigraphic layers in the snow pits are delineated and sampled in detail (for oxygen isotope ratios, microparticles, and major ions), enabling the episodes of snowfall to be characterized in terms of precipitation geochemistry. Ultimately, the analysis of the prevailing meteorological conditions associated with precipitation events, as measured at the stations, combined with regional airflow derived from satellite imagery, and reconstructed from NMC [National Meteorological Center, now the National Centers for Environmental Prediction (NCEP)] global analyses, will enable different airflow patterns to be associated with variations in the geochemistry of the snow. This will then provide valuable insight into the interpretation of downcore geochemical variations.

In this paper we provide a description of the Nevado Sajama station design and operation and present a discussion of observations through the first annual cycle (October 1996 to September 1997). This new station is $1000 \mathrm{~m}$ higher in altitude than any other in either North or South America and will be operated in conjunction with that on Illimani for several more years. Data from additional years will provide further information on climate variability at these sites. A detailed analysis of the geochemical calibration process will be presented elsewhere.

\section{Regional climate}

The volcano Sajama is the highest mountain in Bolivia; it is located in the southern Tropics, in the western Andean Cordillera, near the border with Chile (Fig. 1). The climate in this area is semiarid, with an average annual precipitation of $316 \mathrm{~mm}$ at the base of Sajama (Sajama Village, 4220 m, 1975-85). However, the interannual precipitation variability in this area is high (Ronchail 1995). During the summer months (November-March) the southern altiplano is mostly influenced by the tropical circulation. Strong convection and afternoon showers are the result of heating and the rising motion of air masses over the altiplano (Garreaud and Wallace 1997). Moisture advection from the interior of the continent (Amazon and Chaco Basins) maintains a high humidity level throughout the summer months (P. Aceituno and A. Montecinos 1997, personal communication). Nevertheless, precipitation events occur in discrete episodes with durations 
of a few days rather than being a constant feature. In contrast, the winter season is normally dry, interrupted only by occasional outbreaks of polar air masses from the Pacific (cold fronts or upper-air lows) that sometimes lead to snowfall even as far north as Sajama (Vuille and Ammann 1997).

The main features of the tropospheric circulation over this part of the Andes have been described in a variety of studies (Virji 1981; Nishizawa and Tanaka 1983; Chu 1985; Fuenzalida and Rutllant 1987; Horel et al. 1989; Hoffmann 1992; Jacobeit 1992; NoguésPaegle and Mo 1997; P. Aceituno and A. Montecinos 1997, personal communication). In order to sustain convection and associated precipitation, the upper-air circulation plays a crucial role. Only upper-air divergence or strong easterly wind anomalies provide favorable conditions for precipitation (Jacobeit 1992). During periods of upper-air convergence, convection and precipitation are suppressed. Normally, this upperair divergence, necessary to sustain convection, is associated with anticyclonic outflow from an upper-level high pressure system ("Bolivian high"). However, even as new and improved datasets have recently become available (e.g., Hastenrath 1997), and general circulation models have been shown to be very useful (e.g. Figueroa et al. 1995; Lenters and Cook 1995, 1997), many features of the atmospheric circulation over the altiplano remain unclear. The AWS on Nevado Sajama will therefore serve both to improve our knowledge about the climate at the ice-core site and provide new insight about the midtropospheric circulation (450-hPa level) over this part of the central Andes (cf. Vuille et al. 1998).

\section{Sajama station design and equipment}

We designed the Sajama station to allow recovery of near-real-time measurements, and to provide the assurance of on-site data storage. The remote, highelevation location of the station precludes unscheduled service or repair visits, and immediate recovery of the data stream was desired, permitting analyses important to the ice-core paleoclimate project to begin. Therefore, mechanical and electrical reliability was essential, along with satellite telemetry. Excepting the custom-built tower, we used wellproven, commercially available components, configured to meet the demands of the site and project objectives (Fig. 2).
The tower is an adaptation of a design used by K. Steffen (University of Colorado) for the Greenland Climate Network (http://cires.colorado.edu/people/ steffen.group/gc-net.html). On Sajama, aluminum tubing is used throughout (6061 T6 alloy), with a 3-in. diameter, 0.25-in. wall thickness mast, the height of which can be extended as snow accumulates at the site. Horizontal supports are 1-in. diameter schedule 80 pipe to reduce vibration in high velocity winds, attached to the vertical mast by plates that can be easily adjusted upward.

Measurement and control functions are accomplished by a Campbell Scientific, Inc. (CSI), model CR10X datalogger. The reliability of the instrument has been well proven, with an estimated mean time between failures of $160 \mathrm{yr}$. With the current measurement and control program, the datalogger has sufficient memory to store 20 months of data, while a solid-state data storage module provides an addi-

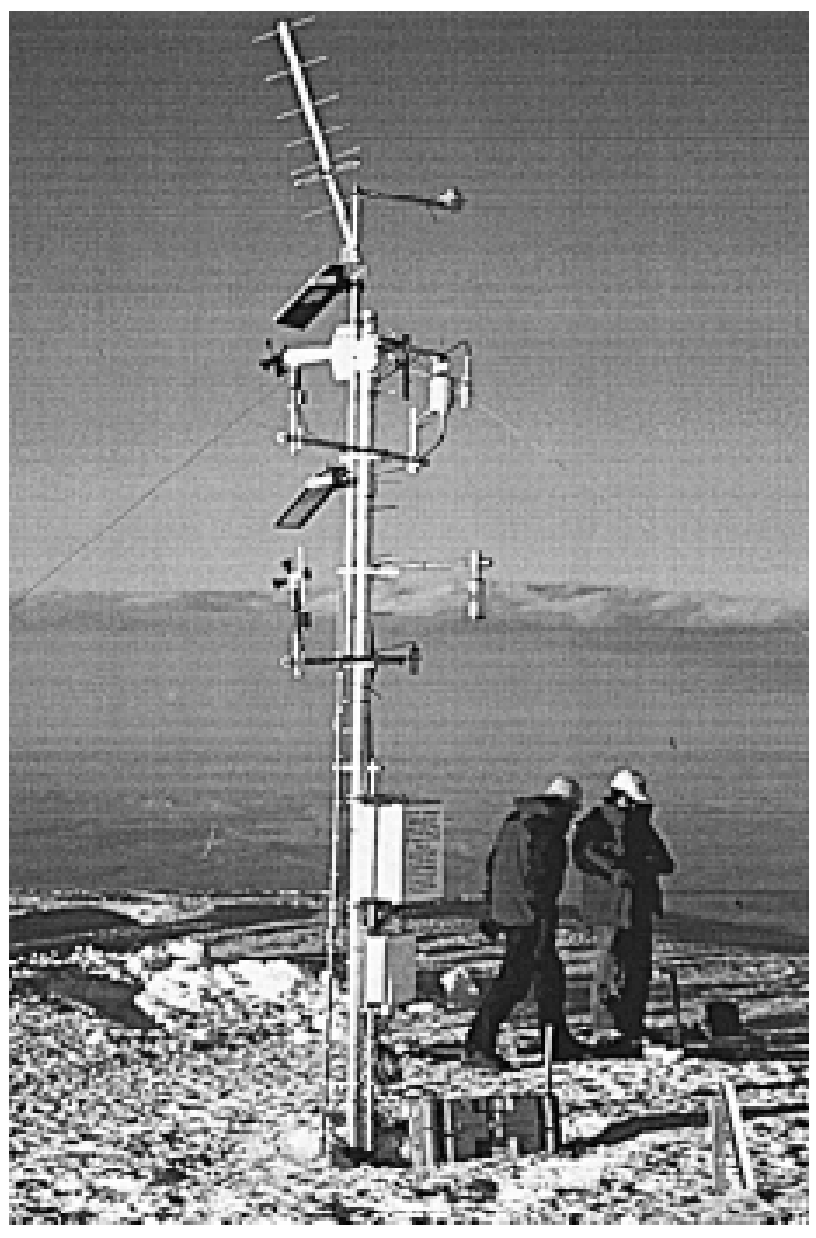

FIG. 2. Automated weather station at the summit of Nevado Sajama (6542 m), 1 July 1997. GOES antenna is oriented to $68^{\circ}$ true (ENE). 
tional 12 months of on-site capacity. Both of these devices are provided with 4-6 yr of backup power by independent lithium batteries, in the event of primary power failure. Both were temperature tested at CSI by repeatedly cycling them between $-55^{\circ}$ and $+85^{\circ} \mathrm{C}$. Satellite telemetry is being provided by a Geostationary Operational Environmental Satellite (GOES) at an interval of $3 \mathrm{~h}$, using a Telonics TGT1 transmitter. The datalogger, transmitter, and peripheral electronics are installed and housed in a sealed, fiberglass enclosure that was carried to the site already assembled.

Most of the sensors used at the station (Table 1) received extended temperature testing or special calibration for the anticipated conditions at the summit. All sensors are controlled by the CR10X datalogger, with measurement and processing intervals that vary between sensors (Table 1). Data are processed by the datalogger hourly, then sent to storage and the transmitter. As indicated in the table, several additional measurements began in July 1997, when the supplemental sensors were installed.

Several experiments are being conducted at the station to help evaluate the quality of measurements. For example, identical temperature and relative humidity probes are housed in two different radiation shields; one is aspirated by a blower and the other is naturally ventilated. This test is providing information about solar loading effects on temperature and humidity measurements at high elevation. Two ultrasonic snow depth sensors are situated $2 \mathrm{~m}$ apart, allowing a more accurate determination of accumulation or ablation by averaging measurements at two sites. These two sensors also permit better temporal coverage, as during

TABLE 1. Sajama weather station sensors and measurements. All heights are at the time of the 1997 service and upgrade visit (1 July 1997). The Illimani station configuration is similar.

\begin{tabular}{|c|c|c|c|c|c|}
\hline Variable & $\begin{array}{l}\text { Sensor manufacturer/ } \\
\text { model }\end{array}$ & $\begin{array}{c}\mathbf{Z}_{\text {initial }} \\
(\mathbf{m})\end{array}$ & $\begin{array}{c}\text { Sampling } \\
\text { interval }\end{array}$ & $\begin{array}{r}\text { Dat } \\
\text { interval }\end{array}$ & $\begin{array}{l}\text { ed and transmitted } \\
\text { data (units) }\end{array}$ \\
\hline Wind speed (upper) & R.M. Young 05103 & 3.7 & $60 \mathrm{~s}$ & $\begin{array}{c}1 \mathrm{~h} \\
1 \mathrm{~h} \\
24 \mathrm{~h}\end{array}$ & $\begin{array}{l}\text { Mean horizontal speed }\left(\mathrm{m} \mathrm{s}^{-1}\right) \\
\text { Resultant mean speed }\left(\mathrm{m} \mathrm{s}^{-1}\right) \\
\text { Maximum 1-min speed }\left(\mathrm{m} \mathrm{s}^{-1}\right) \\
\text { time of, and temperature at time }\end{array}$ \\
\hline Wind speed (lower) & R.M. Young 05103 & 2.7 & $60 \mathrm{~s}$ & $\begin{array}{l}1 \mathrm{~h} \\
1 \mathrm{~h}\end{array}$ & $\begin{array}{l}\text { Mean horizontal speed }\left(\mathrm{m} \mathrm{s}^{-1}\right) \\
\text { Resultant mean speed }\left(\mathrm{m} \mathrm{s}^{-1}\right)\end{array}$ \\
\hline Wind direction (upper) & R.M. Young 05103 & 3.7 & $60 \mathrm{~s}$ & $\begin{array}{l}1 \mathrm{~h} \\
1 \mathrm{~h}\end{array}$ & $\begin{array}{l}\text { Resultant mean direction (deg.) } \\
\text { Std dev direction ( } 5 \text { subintervals) }\end{array}$ \\
\hline Wind direction (lower) & R.M. Young 05103 & 2.7 & $60 \mathrm{~s}$ & $\begin{array}{l}1 \mathrm{~h} \\
1 \mathrm{~h}\end{array}$ & $\begin{array}{l}\text { Resultant mean direction (deg.) } \\
\text { Std dev direction ( } 5 \text { subintervals) }\end{array}$ \\
\hline Barometric pressure & Setra 270 & & $1 \mathrm{hr}$ & $1 \mathrm{~h}$ & Station pressure $(\mathrm{hPa})$ \\
\hline $\begin{array}{l}\text { Air temperature } \\
\text { (aspirated shield) }\end{array}$ & Vaisala HMP35C & 3.7 & $10 \mathrm{~min}$ & $\begin{array}{l}1 \mathrm{~h} \\
1 \mathrm{~h}\end{array}$ & $\begin{array}{l}\text { Mean air temperature }\left({ }^{\circ} \mathrm{C}\right) \\
\text { Max air temperature }\left({ }^{\circ} \mathrm{C}\right) \text {, time } \\
\text { of, and 3.7-m wind speed at time }\end{array}$ \\
\hline $\begin{array}{l}\text { Airflow check, } \\
\text { aspirated shield }\end{array}$ & $\begin{array}{l}\text { Gill } 43408 \\
\text { (R.M. Young) }\end{array}$ & 3.7 & $10 \mathrm{~min}$ & $1 \mathrm{~h}$ & $\begin{array}{l}\text { Mean of } \mathrm{n}=6 \text { checks (at each } \\
\text { check, } 0 \text { if switch open, } 2 \text { if } \\
\text { closed) }\end{array}$ \\
\hline $\begin{array}{l}\text { Air temperature } \\
\text { (naturally ventilated shield) }\end{array}$ & Vaisala HMP35C & 3.7 & $10 \mathrm{~min}$ & $\begin{array}{l}1 \mathrm{~h} \\
1 \mathrm{~h}\end{array}$ & $\begin{array}{l}\text { Mean air temperature }\left({ }^{\circ} \mathrm{C}\right) \\
\text { Max air temperature }\left({ }^{\circ} \mathrm{C}\right) \text {, time } \\
\text { of, and 3.7-m wind speed at time }\end{array}$ \\
\hline $\begin{array}{l}\text { Relative humidity } \\
\text { (aspirated shield) }\end{array}$ & Vaisala HMP35C & 3.7 & $10 \mathrm{~min}$ & $1 \mathrm{~h}$ & Mean relative humidity (\%) \\
\hline
\end{tabular}


precipitation events the acoustic signal quality is sometimes diminished.

Electrical power to the station is provided by two independent 12V DC systems. Both use 10-W solar panels and regulators to recharge sealed lead-acid batteries (24 and $25 \mathrm{~A} \mathrm{~h}$ ). One system supplies 420$480 \mathrm{~mA}$ to the aspirated radiation shield fan and provides power to the infrared temperature transducer. The datalogger, transmitter, and sensors are powered by the second system.

Prior to shipment to Bolivia, the complete station was assembled and operated using one of the GOES test channels. Considerable effort was made to ensure successful installation of the station on Sajama, at an altitude where reduced oxygen concentration can impair human judgment. Fittings and hardware were carefully labeled, and details were documented on photographic prints. As further insurance, each member of the team from the University of Massachusetts was sufficiently familiar with station assembly to lead the assembly effort, in the event of altitude-related physiological problems among the group. At the summit of Sajama, a site was chosen slightly to the northeast that is not directly within view from the highest point, to minimize disturbance of the station by any of the estimated 100 climbers reaching the summit each year.

\section{Station operation}

The Sajama station was installed on 1 October 1996, shortly before the 1996-97 accumulation season began. In June-July of 1997 eight days were spent

TABLE 1. (Continued)

\begin{tabular}{|c|c|c|c|c|c|}
\hline Variable & $\begin{array}{c}\text { Sensor manufacturer/ } \\
\text { model }\end{array}$ & $\begin{array}{l}Z_{\text {initial }} \\
(\mathbf{m})\end{array}$ & $\begin{array}{l}\text { Sampling } \\
\text { interval }\end{array}$ & $\begin{array}{r}\text { Dat } \\
\text { interval }\end{array}$ & $\begin{array}{l}\text { ed and transmitted } \\
\text { data (units) }\end{array}$ \\
\hline $\begin{array}{l}\text { Relative humidity } \\
\text { (naturally ventilated shield) }\end{array}$ & Vaisala HMP35C & 3.7 & $10 \mathrm{~min}$ & $1 \mathrm{~h}$ & Mean relative humidity (\%) \\
\hline Vapor pressure & calculated (asp. sensors) & 3.7 & $10 \mathrm{~min}$ & $1 \mathrm{~h}$ & Mean vapor pressure $(\mathrm{kPa})$ \\
\hline $\begin{array}{l}\text { Incoming solar } \\
\text { radiation; global }\end{array}$ & Eppley 8-48 & 4.5 & $60 \mathrm{~s}$ & $1 \mathrm{~h}$ & $\begin{array}{l}\text { Mean incoming } \\
\text { irradiance }\left(\mathrm{kW} \mathrm{m}^{-2}\right)\end{array}$ \\
\hline $\begin{array}{l}\text { Reflected solar } \\
\text { radiation; global }\end{array}$ & LI-COR L1200X & 2.7 & $60 s$ & $1 \mathrm{~h}$ & Mean refl. irradiance $\left(\mathrm{kW} \mathrm{m}^{-2}\right)$ \\
\hline $\begin{array}{l}\text { Snow accumulation/ablation } \\
\text { (SW sensor) }\end{array}$ & Campbell Scientific SR50 & 2.47 & $\begin{array}{l}1 \mathrm{hr} \\
1 \mathrm{hr}\end{array}$ & $1 \mathrm{~h}$ & $\begin{array}{l}\text { Distance to snow surface (m) } \\
\text { SW quadrant } \\
\text { Quality of measurement above } \\
\text { (dimensonless integer) }\end{array}$ \\
\hline $\begin{array}{l}\text { Snow accumulation/ablation } \\
\text { (NE sensor) }\end{array}$ & Campbell Scientific SR50 & 2.57 & $1 \mathrm{hr}$ & $1 \mathrm{~h}$ & $\begin{array}{l}\text { Distance to snow } \\
\text { surface (m) NE quadrant } \\
\text { Quality of measurement above } \\
\text { (dimensionless integer) }\end{array}$ \\
\hline $\begin{array}{l}\text { Forward and reflected power } \\
\text { (from/to satellite transmitter) }\end{array}$ & & & $3 \mathrm{hr}$ & $3 \mathrm{~h}$ & $\begin{array}{l}\text { Forward and reflected power } \\
\text { (decimal units) }\end{array}$ \\
\hline Snow surface temperature* & Everest Interscience 4000B & 2.3 & $10 \mathrm{~min}$ & $1 \mathrm{~h}$ & Mean surface temperature $\left({ }^{\circ} \mathrm{C}\right)^{*}$ \\
\hline Air temperature gradient* & $\begin{array}{l}\text { Type E thermocouples } \\
\text { (custom) }\end{array}$ & $\begin{array}{c}0.03,1.03 \\
2.03,3.7\end{array}$ & $10 \mathrm{~min}$ & $1 \mathrm{~h}$ & $\begin{array}{l}\text { Mean temperature gradient } \\
\left({ }^{\circ} \mathrm{C} \text { between sensors }\right)^{*}\end{array}$ \\
\hline Snow/firn temperature* & $\begin{array}{l}\text { Thermometrics } \\
\text { thermistors }\end{array}$ & $0.15,-1.85$ & $10 \mathrm{~min}$ & $1 \mathrm{~h}$ & $\begin{array}{l}\text { Snow temperature (1.85-m } \\
\text { depth only on } 1 \text { July)* }\end{array}$ \\
\hline
\end{tabular}

*Installed June 1997. 
at the site, midway through the 1997 ablation season, at which time the station was inspected and serviced. The heights of all sensors were raised, and several additional sensors were installed (Table 1).

Data from the station are accessible in two ways. At the site, the solid-state data storage module can be quickly replaced by another, allowing the complete dataset to be downloaded in an environment more hospitable to computers. In addition, the telemetered data are accessed daily through the National Environmental Satellite, Data and Information Service (NESDIS) of the National Oceanic and Atmospheric Administration. In the climatology lab at the University of Massachusetts (department of geosciences), integrated scripts and batch programs automatically dial in to NESDIS in Virginia and acquire the data, screen all variables and flag those outside a predefined range, and transfer a backup of each file to another computer. Every few days a series of graphs is constructed from a template, which provides an additional, rapid quality control overview. Graphs of near-realtime data from the station are available from the climatology lab Web site (http://www.geo.umass.edu/ climate/bolivia.html).

The telemetry of data from Sajama has been very successful. Through the first two months of station operation (October and November 1996), only two transmissions were not received $(0.4 \%$ loss $)$. During the climatological wet-season months of DecemberFebruary, the recovery of transmissions was significantly diminished only during January, when $20.6 \%$ were lost. By March, recovery was nearly complete again at $99.2 \%$ (6 h lost), increasing to $99.6 \%$ for April through August. Each message recovered from NESDIS contains the data from the station, as well as a header containing parameters evaluating the signal and quality of data received by GOES. This information has been useful as a diagnostic tool; most of the transmission problems that have occurred were the result of snow on the antenna. Typically, less than $1 \%$ of the power transmitted by the station is reflected, but during intervals when snow is accumulating, the proportion of power reflected increases, and data quality decreases from good to fair and then to poor (quality as assessed by NESDIS). When more than $\sim 40 \%$ is reflected, the NESDIS message indicates that the scheduled transmission was not received. Evidence for an association between snowfall and transmission problems is often provided by other parameters. Snow accumulation is also often indicated by the snow depth sensors at times of increased power reflection, as is a decrease in data quality as measured by these sensors. In addition, when the surface albedo is greater than one (the ratio of incoming to reflected solar irradiance), the upward-looking pyranometer dome must be partially obscured. Fortunately, snow clears off the equipment quite rapidly following snowfall events, probably due to the intensity of solar radiation and infrequency of calm conditions at $6500 \mathrm{~m}$.

The telemetry of data from the Sajama datalogger and transmitter via GOES has proven to be very accurate. To evaluate the telemetry error rate, we compared all hourly data stored on site with that received from NESDIS ( $n=176715$ values). Only 15 discrepancies were identified, six of which we deemed to be trivial (0.4\%-2.8\% difference in values). All but one of the discrepancies was contained within a message (transmission) identified by NESDIS as being "received with parity errors." The error rate over the period examined is effectively only $1: 176715$ or 6 $\times 10^{-6}$, which is approximately the "normal" error rate specification from NESDIS.

The most significant problem to date with the station was due to greater than anticipated snowfall during the austral summer of 1996-97. Based on a short ice-core record recovered in 1993, the annual snow accumulation at the summit in water equivalence averages $0.4 \mathrm{~m}$ (L.G. Thompson 1995, personal communication). Thus, the lowest sensors on the station were positioned $\sim 2 \mathrm{~m}$ above the snow surface. However, the 1996-97 summer was wet on the altiplano, and on Sajama we estimate that the snowpack reached $4 \mathrm{~m}$ (see section 5f). The accumulation of snow at the site resulted in temporary burial of some sensors. The prevalence of wind crusts within the snowpack added considerable strength, and as the snowpack consolidated there was tremendous downward pressure, which damaged the lower wind sensor. Burial of the lowest sensors notwithstanding, the station was found in excellent condition at the June 1997 visit, with all equipment except the lower wind sensor functioning. Tilting of the mast was less than $4^{\circ}$, and no detectable change in the antenna azimuth indicated that no rotational motion had occurred.

\section{Annual and daily cycles on Sajama}

To investigate diurnal patterns and the annual cycle through the first year of observations on Sajama, a dataset of hourly values was compiled from datalogger storage (01002 October 1996 to 120027 
June 1997) and via GOES telemetry (1100 28 June to 0000 2 October 1997). ${ }^{1}$ Within the dataset there are $69 \mathrm{~h}$ missing due to station relocation in late June. Otherwise, gaps are generally only $1-3 \mathrm{~h}$ duration (due to transient telemetry problems), resulting in a dataset that is 98.9\% complete for most variables. With two exceptions, the values used here are hourly means based on either 10 or 60 measurements, made during the preceding hour (Table 1). The exceptions are station pressure and distance to snow, which are actual hourly measurements. All daily minima and maxima (e.g., temperature) represent the minimum and maximum hourly mean values each day, rather than individual extreme values.

\section{a. Pressure}

The amplitude of the annual change in barometric pressure on Sajama is very small, remaining within a range of $10 \mathrm{hPa}$ all year (Fig. 3a). Generally higher pressure during an extended summer season (i.e., November-April) reflects the establishment of an annually recurring, upper-air high ("Bolivian high") over Bolivia. The lowest annual pressure values were reached during Southern Hemisphere winter in the course of the northward displacement of the planetary west wind zone, and winter season drops in pressure are mainly restricted to single events, when extratropical upper-air lows are cut off and displaced north toward the altiplano (Vuille and Ammann 1997).

Through the entire annual cycle, a notable feature is the 12-hourly pressure tide, with a constant ampli-

${ }^{1}$ Local standard time (LST) is used throughout this paper (UTC $-4 \mathrm{~h})$.
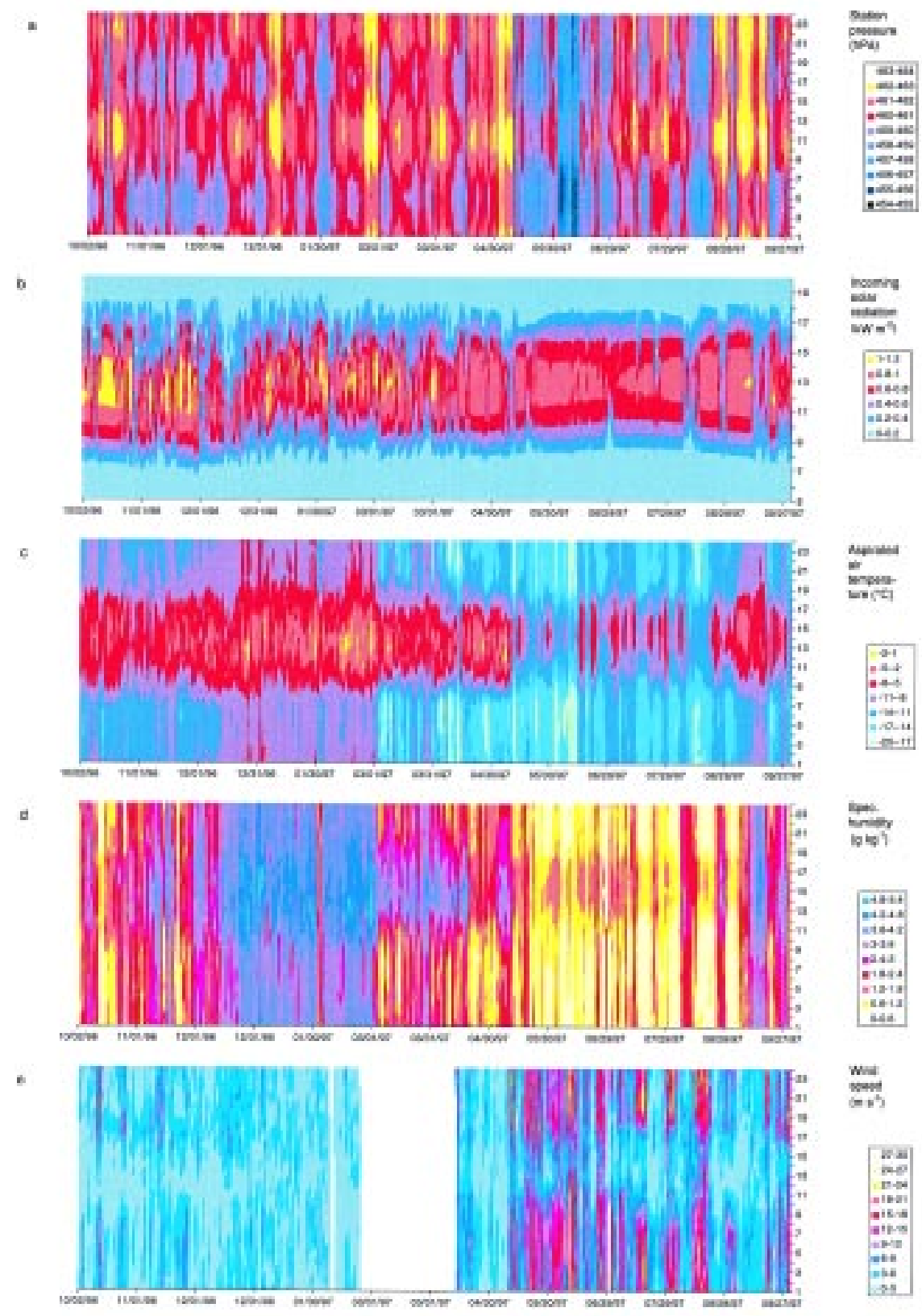

FIG. 3. Color isopleth diagrams (daily versus hourly values) for the period 01002 October 1996 to 00002 October 1997 (LST). Shown from top to bottom are (a) station pressure (hPa), (b) incoming solar irradiance $\left(\mathrm{kW} \mathrm{M}^{-2}\right)$, (c) aspirated air temperature $\left({ }^{\circ} \mathrm{C}\right)$, (d) specific humidity $\left(\mathrm{g} \mathrm{kg}^{-1}\right)$, and (e) wind speed $\left(\mathrm{m} \mathrm{s}^{-1}\right)$. Wind data are missing between 23 February and 13 April 1997 (see text). Note different $y$-axis scale for irradiance plot.

tude of $1-2 \mathrm{hPa}$ and maxima around 1130 and 2230 LST (Fig. 4).

\section{b. Incoming solar radiation}

Following the seasonal march of the sun, daily solar irradiance maxima ranged between approximately $1200 \mathrm{~W} \mathrm{~m}^{-2}$ during the summer and $800 \mathrm{~W} \mathrm{~m}^{-2}$ at the winter solstice (Fig. 5). Measured clear-sky glo- 


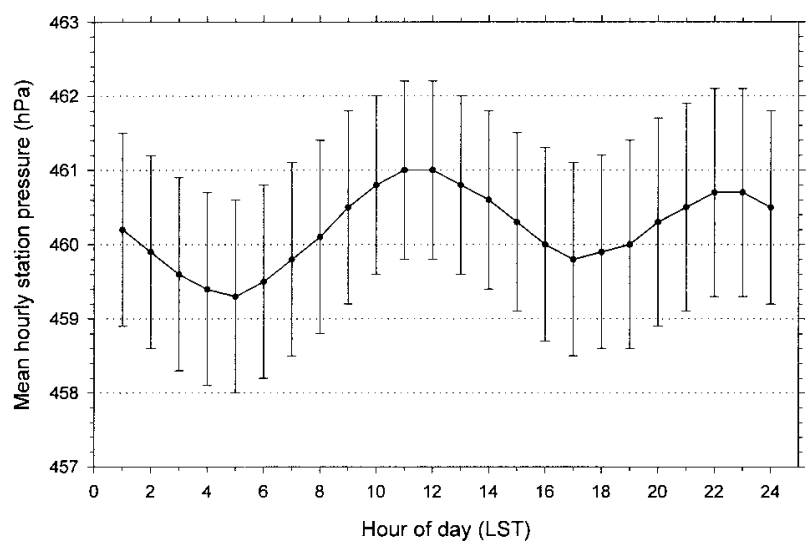

FIG. 4. Daily cycle of mean hourly barometric pressure (hPa), 2 October 1996 to 1 October 1997. Error bars for each hour are \pm 1 std dev.

bal irradiance maxima were typically $85 \%$ of calculated direct irradiance on a horizontal surface at the top of the atmosphere, reflecting the altitude of the station and the dry atmosphere above the altiplano. Total daily radiation receipts on Sajama were greatest during the spring months of October and November (Fig. 5), which is in agreement with data reported from the Chilean altiplano by P. Aceituno and A. Montecinos (1997, personal communication). During the summer months December-February, and extending into March, moisture advection and afternoon convective cloud cover over the altiplano significantly reduced the daily receipt of solar radiation (Fig. 3b). Cloud cover was reduced through the winter, as indicated by the accordance of daily irradiance maxima (Fig. 5) and the regularity of the daily cycle (Fig. 3b), interrupted only by the passage of occasional cold fronts.

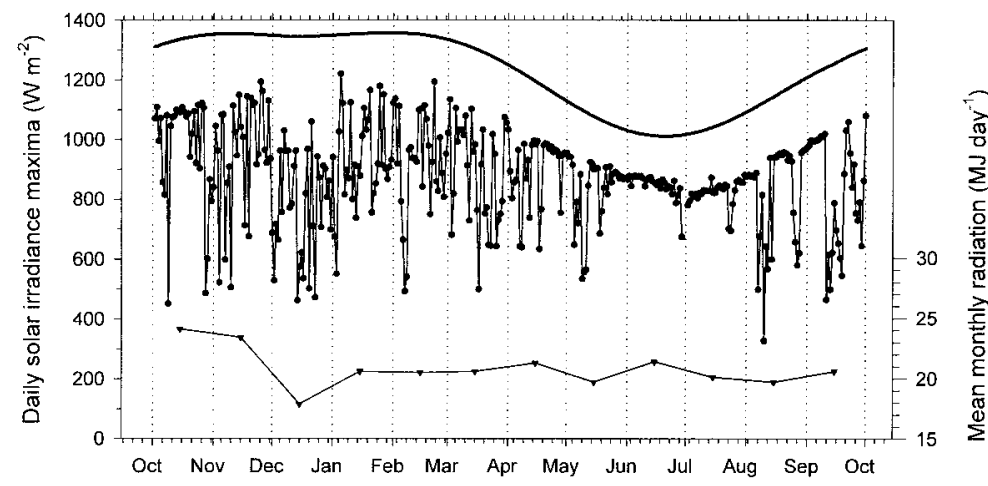

FIG. 5. Sajama maximum solar irradiance each day, in $\mathrm{W} \mathrm{m}^{-2}$ from hourly values (line with circles), and monthly mean daily radiation received, in $\mathrm{MJ}_{\text {day }^{-1}}$ (line with triangles). Also shown is the maximum daily top-of-atmosphere irradiance (horizontal surface, in $\mathrm{W} \mathrm{m}^{-2}$ ) at the location of Sajama (heavy line), from hourly calculations made on the hour, LST.
Solar irradiance measurements from AWS always require cautious interpretation, as snow accumulation on the radiometer dome under certain conditions during precipitation events results in an apparent reduction in irradiance. Some measurements must therefore be considered minimum estimates. To investigate the extent of this problem on Sajama, we compared halfday totals of top-of-the-atmosphere calculated radiation receipts with those measured at the station (i.e., sunrise to 1200 LST and 1201 to sunset; both in MJ). General agreement is evident between the patterns of calculated and measured radiation receipts in the morning (Fig. 6). The greatest deviations are apparent during December-February, the primary months of snow accumulation (with lesser deviations during March and September). Figure $3 b$ illustrates that measured irradiance through the morning hours is less regular (more variable) during these months, when a seasonal increase in moisture advection often results in morning cloudiness. However, the associated snowfall must also account for some of the discrepancy between the patterns in summer. Nonetheless, the accordance through most of the annual cycle of the measured and calculated patterns, in the typically cloud-free morning, suggests that the measured data represent the radiation regime at the site reasonably well.

The afternoon pattern of measured receipts differs significantly from that calculated (Fig. 6). Considerable day-to-day variability in afternoon irradiance occurs on Sajama (Fig. 3b), which we attribute primarily to clouds. Indeed, convective cloudiness in this region of South America is well documented. Cloud cover typically increases rapidly between 1200 and 1700, reaching a maximum around 1800 , followed by a decrease until midnight (Garreaud and Wallace 1997). The distinct morning and afternoon patterns of radiation receipt (Fig. 6) suggest that afternoon cloudiness occurs through much of the year on Sajama, though to a lesser extent during the winter.

\section{c. Air temperature}

Tropical locations typically experience relatively little temperature change through the course of the year. Although the Sajama station can still be considered tropical, it is located at the very southern edge of the Tropics and is strongly influenced by extratropical circulation in the 
winter season. As a result, there is a quite distinct change in air temperature throughout the year (Fig. 3c). Temperatures generally followed the annual cycle of solar radiation, with monthly means ranging from $-7.5^{\circ} \mathrm{C}$ in January to $-14.1^{\circ} \mathrm{C}$ in June. Due to the lowlatitude, high-elevation location of Sajama, the mean daily amplitude of air temperature in each month of the year was greater than the annual range in mean monthly temperature $\left(6.6^{\circ} \mathrm{C}\right)$. April was the month of greatest variability, with a standard deviation about the daily mean of $4.6^{\circ}$ and a range between the mean maximum and minimum temperatures of $13.1^{\circ} \mathrm{C}$. Overall, the period from October 1996 to September 1997 was unusually cold on the altiplano, as discussed further below.

Through the first year of the Sajama AWS operation, air temperature at the site has essentially remained below $0^{\circ} \mathrm{C}$ (Fig. 7). This cannot be stated more definitively, however, due to the difficulty of air temperature measurement at $6500 \mathrm{~m}$, at varying height above the snow surface. The highest hourly mean temperature reached within the aspirated radiation shield was $1.5^{\circ} \mathrm{C}$, with four other positive values between $0.0^{\circ}$ and $0.7^{\circ} \mathrm{C}$ (all in late February). In all five cases the sensor was either very close to the snow surface or buried by snow. A temperature maximum was also recorded each day from among the set of all aspirated temperature measurements, made every $10 \mathrm{~min}$ (not shown). One extreme, of $1.7^{\circ} \mathrm{C}$, was recorded on 25 January when the sensor was $\sim 1.25 \mathrm{~m}$ above the snow surface. Although the wind speed at the same time was $2.2 \mathrm{~m} \mathrm{~s}^{-1}$ (further aiding ventilation of the sensor), the mean temperature for the hour was only $-3.0^{\circ} \mathrm{C}$. This demonstrates that hourly means are more meaningful than instantaneous values on Sajama.

Air temperatures measured within a naturally ventilated shield were often dramatically higher than those in the aspirated shield, with one hourly mean value over $10^{\circ} \mathrm{C}\left(\sim 120025\right.$ January; $1.0 \mathrm{~m} \mathrm{~s}^{-1}$ wind, hourly mean $\left.T_{\text {asp. }}=-2.8^{\circ} \mathrm{C}\right)$. Clearly, aspiration of temperature sensors is essential in environments such as these where radiation loading may significantly affect the accuracy of temperature measurements.

Within the annual cycle of 1996-97 air temperature minima and maxima on Sajama (Fig. 7), there are two noteworthy examples of sudden and persistent drops in temperature (see also Fig. 3c). The first was at the beginning of March, when daily minima decreased $\sim 8^{\circ} \mathrm{C}$. This was followed in mid-May by a similar magnitude drop in daily maxima. Between these events, the daily amplitude of air temperature
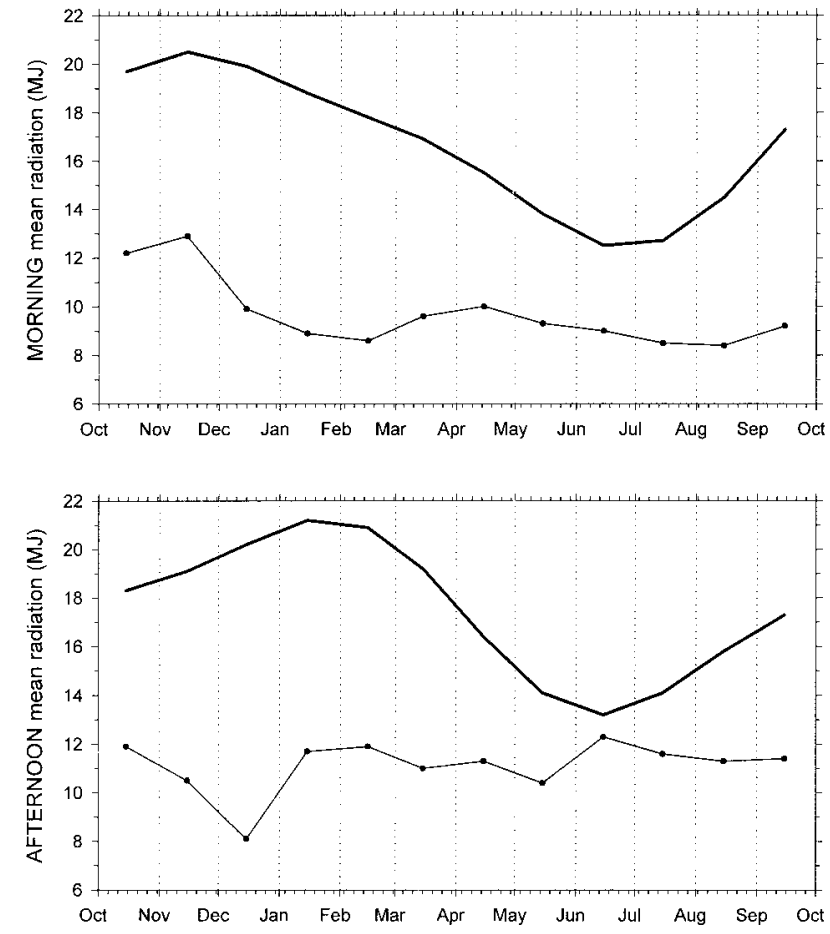

FIG. 6. Mean monthly mean solar radiation receipts on Sajama during the morning (until 1200 LST) (top) and afternoon (bottom). Measured values (line with circles) are derived from hourly means, and those for a horizontal surface at the top of the atmosphere are based on hourly calculations (heavy line).

increased quite dramatically to a mean of $12.2^{\circ} \mathrm{C}$, in contrast to mean monthly ranges for individual months excluding this period which only varied between $6.5^{\circ}$ and $8.0^{\circ} \mathrm{C}$ (Fig. 8, top). This period of increased diurnal temperature range overlaps the interval when we have evidence that the temperature and humidity sensors may have been buried by snow (approximately early March to mid-April). It is there-

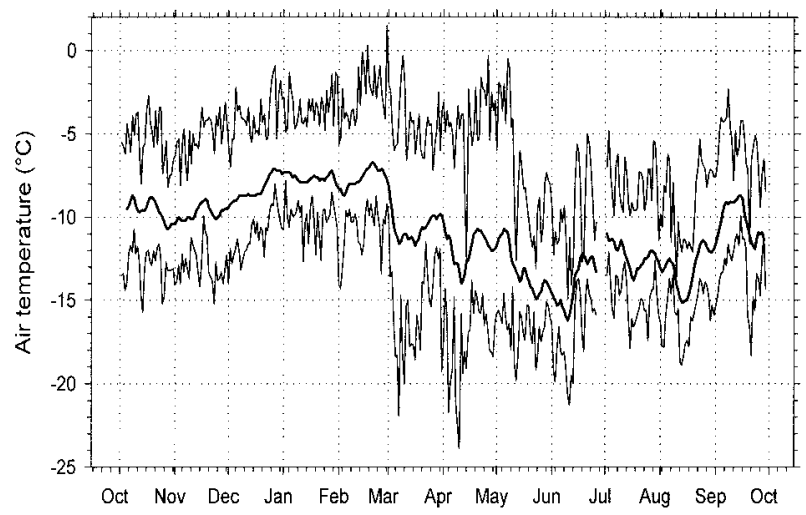

FIG. 7. Sajama daily maximum and minimum air temperatures (thin lines), shown with mean daily temperature (thick line; 9-day smooth). Hourly mean values were used to determine the daily maxima and minima; daily means are of 10-min measurements. 

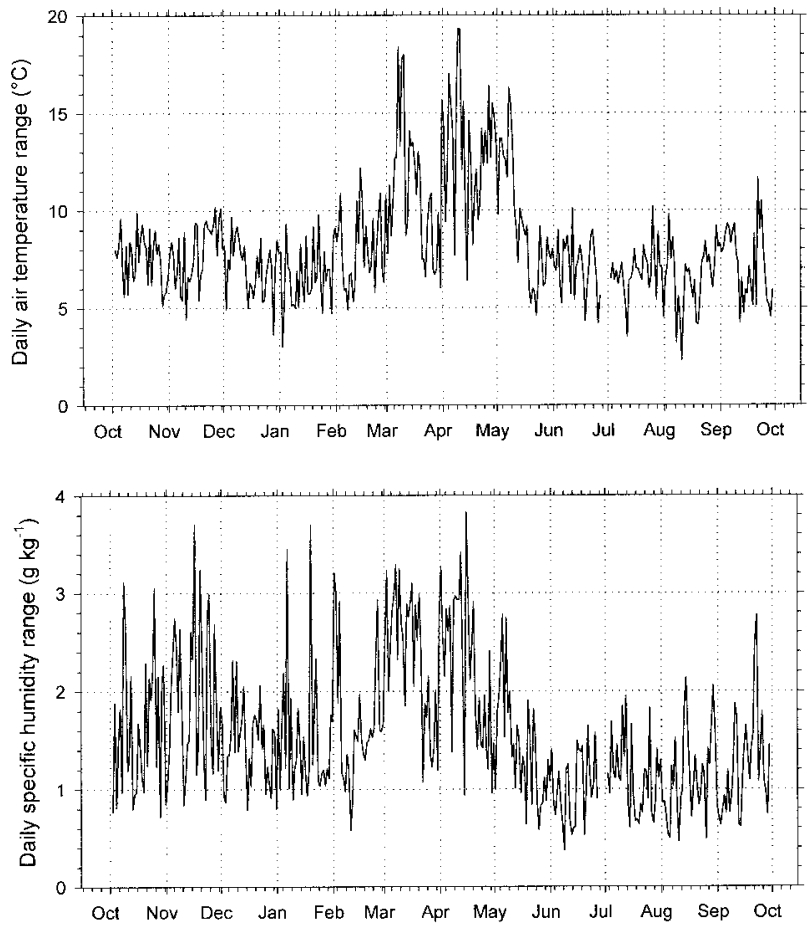

FIG. 8 . The daily range in air temperature (top) and specific humidity (bottom) on Sajama, determined as the difference between the maximum and minimum hourly mean values each day.

fore of considerable importance to assess whether the range increase is spurious or reflects real climatic variability.

Abundant evidence suggests that the increased daily range in air temperature from early March to mid-May is reflective of actual synoptic conditions, despite probable sensor burial. Coinciding with the early March drop in minima at the station was a decrease in minima elsewhere on the altiplano (Fig. 9). Significant changes in other variables measured on Sajama were also associated with the decrease. For example, solar radiation receipts during the morning hours increased dramatically coincident with the drop in temperature minima (Fig. 3b), suggesting fewer overnight clouds and increased radiational cooling. Specific humidity also decreased abruptly, and remained lower (Fig. 3d), while the daily range in water vapor content increased (Fig. 8, bottom). At the time of the temperature decrease there was an unusually rapid, large drop in station pressure (Fig. 3a), and simultaneous lowering of geopotential heights at $450 \mathrm{hPa}$ obtained from daily NCEP analyses. Wind data are not available from the station at this time (due to sensor burial by snow), but zonal winds obtained from NCEP output increased sharply, coinciding with a drop in temperature (especially at $400 \mathrm{hPa}$ ). When the

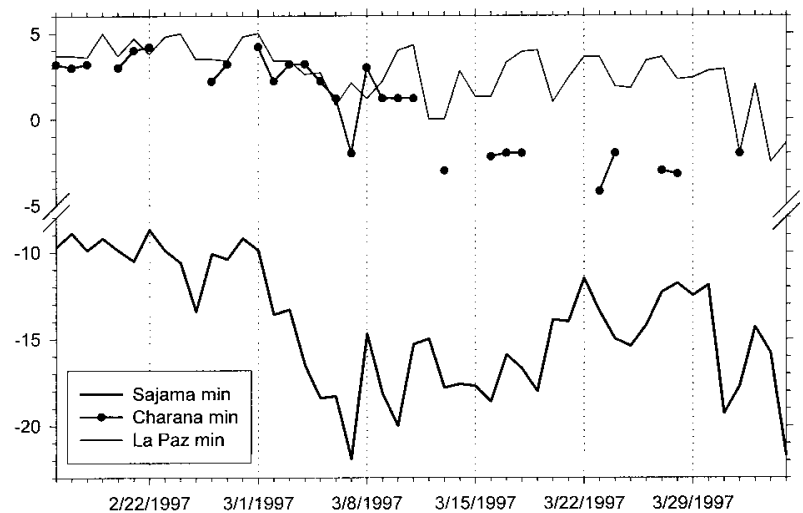

FIG. 9. Minimum daily temperatures on Sajama, and Bolivian weather stations La Paz El Alto (4014 m, 16 $31^{\circ} \mathrm{S}, 68^{\circ} 11^{\prime} \mathrm{W}$ ) and Charana $\left(4057 \mathrm{~m}, 17^{\circ} 35^{\prime} \mathrm{S}, 69^{\circ} 27^{\prime} \mathrm{W}\right)$ for days when data are available.

mid-May drop in temperature maxima occurred, similar changes were observed in other variables, including a pronounced increase in wind speed at the station and another large steplike decrease in specific humidity (Figs. 3e,d), and a decrease in the daily humidity range (Fig. 8, bottom).

With supporting evidence from several variables, other stations, and NCEP output, we believe that the temperature record from Sajama through this period is essentially correct. If burial by snow did occur, the validity of measurements seems not to have been compromised, perhaps due to the low density of the snow and adequate ventilation by wind. Furthermore, the expected influence of sensor burial is nearly opposite that observed (i.e., decrease in temperature minima and humidity rather than an increase). Therefore, the Sajama station data indicate that the change from the summer to winter season occurred in a few abrupt steps, rather than as a gradual transition over several months.

\section{d. Humidity}

The humidity of the atmosphere on Sajama varies markedly through the course of the year, illustrated by relative humidity extremes recorded in 1996-97 of $0.2 \%$ and $99.9 \%$. Through the summer months of December-February, the median relative humidity was greater than $90 \%$, reflecting a mean specific humidity of $3.6 \mathrm{~g} \mathrm{~kg}^{-1}$ (Fig. 3d). Typically, the humidity level during summer months remains high due to daily injections of water vapor into midtropospheric levels (400-500 hPa) by vertical turbulent transport of moisture from lower levels and advection at this level (P. Aceituno and A. Montecinos 1997, personal com- 
munication). High humidity on Sajama during the wet season is associated with easterly winds, which deliver moisture from the interior of the continent. The summer of 1996-97 was unusually wet on the entire altiplano, as discussed below, so the humidity levels measured represent conditions that are above the longterm average.

The winter season is characterized by very dry conditions (Fig. 3d), when it is not uncommon for relative humidity to remain below $20 \%$ for several consecutive days. Indeed, the median specific humidity through these three months was less than $0.9 \mathrm{~g} \mathrm{~kg}^{-1}$. These dry conditions are commonly interrupted by short periods of high humidity, when moist air episodes related to outbreaks of polar air masses reach the altiplano. These occurrences are also associated with higher wind speeds, lower pressure and air temperature, and sometimes snowfall as far north as Sajama. Examples recorded at the station include two events during August and another in mid-September (Fig. 3).

Superimposed upon the distinct seasonal cycle of humidity is a seasonality of the diurnal cycle. This results in seasonality of snow surface evaporation. Specific humidity on Sajama was always highest in the afternoon (Fig. 3d), with the daily peak lagging the solar irradiance distribution by $1-3 \mathrm{~h}$. Relative humidity also increased in the afternoon, but only during the winter and through intervals when the atmosphere was relatively dry (low specific humidity). When the atmosphere was moist, these two measures of humidity were uncorrelated (Fig. 10), demonstrating the seasonal variability of evaporation on Sajama. Daily fluctuations in relative humidity through the summer (e.g., Fig. 10, January) are largely due to the diurnal fluctuations in temperature, as the actual water vapor content does not change dramatically (Fig. 11). During the winter, however, when the daily range in air temperature is equivalent to that in summer $\left(5^{\circ}-10^{\circ} \mathrm{C}\right.$; see top of Fig. 8), the day-to-day change in water vapor content is much higher (Fig. 11). For example, through the two 10-day periods illustrated in Fig. 10, the median daily increases in specific humidity were $140 \%$ and $840 \%$, for summer and winter (respectively). Although large daily relative increases in specific humidity occur periodically throughout the year (e.g., 1 and 2 February, Fig. 11), turbulent mass transfer (i.e., evaporation) on Sajama is especially vigorous during the winter, when high humidity gradients between the snow surface and the air are augmented by a seasonal increase in wind speed.
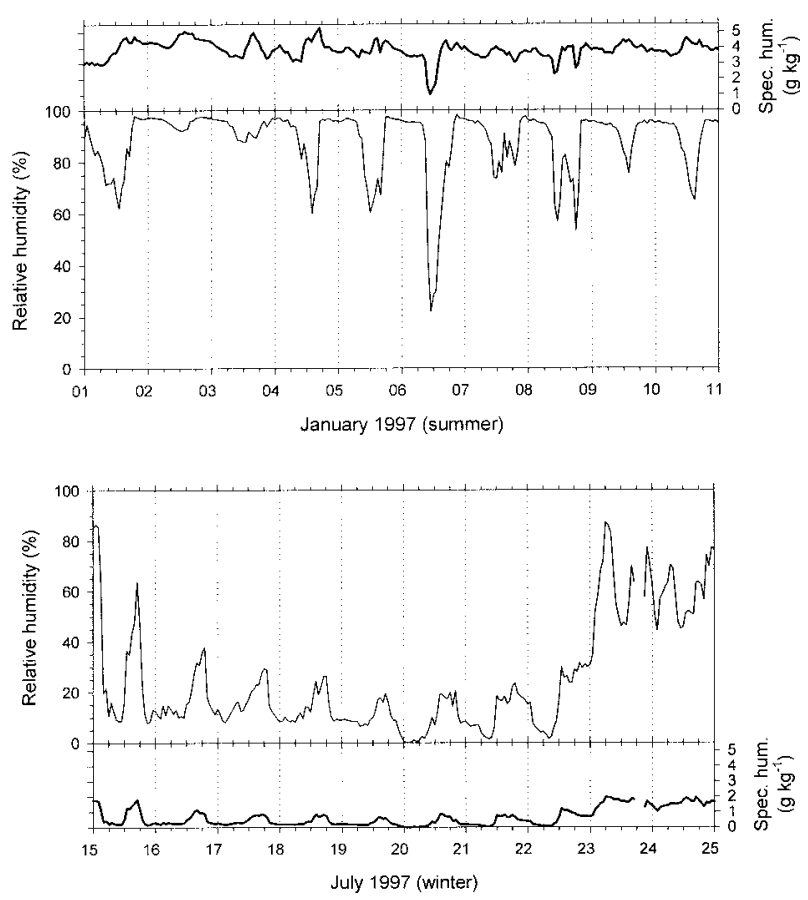

FIG. 10. Ten-day periods of humidity measurements on Sajama, during the summer month of January (top) and in July (bottom).

\section{e. Wind speed and direction}

Wind data are missing from the 1996-97 record between the end of February and mid-April, when both sensors were affected by the unusually heavy summer snowfall. Nonetheless, NCEP output confirms that the most significant change in the wind speed occurred in mid-May, when winds suddenly accelerated and remained high for most of the winter season (Fig. 3e). This increase in wind speed reflects the northward movement of the west wind zone and the subtropical jet, which is typically located at around $25^{\circ} \mathrm{S}$ in June. Through the winter, the wind was steadily from the north and northwest (Fig. 12) and the Sajama region experienced several months of high wind speeds, as-

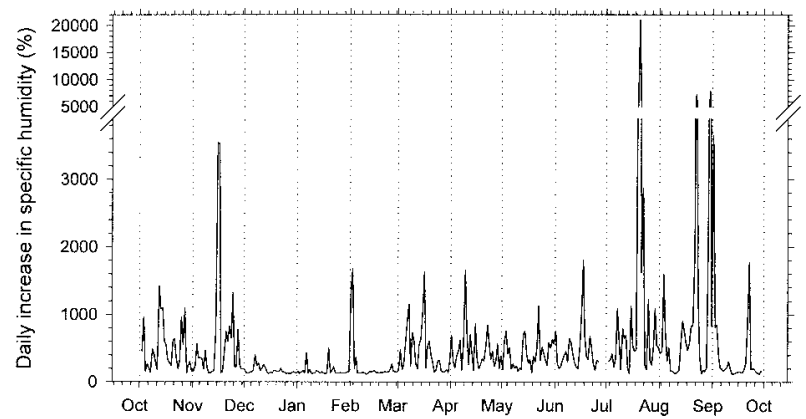

FIG. 11 . The relative change in specific humidity each day (percent increase), calculated as (maxima $\div$ minima) $\times 100$. 


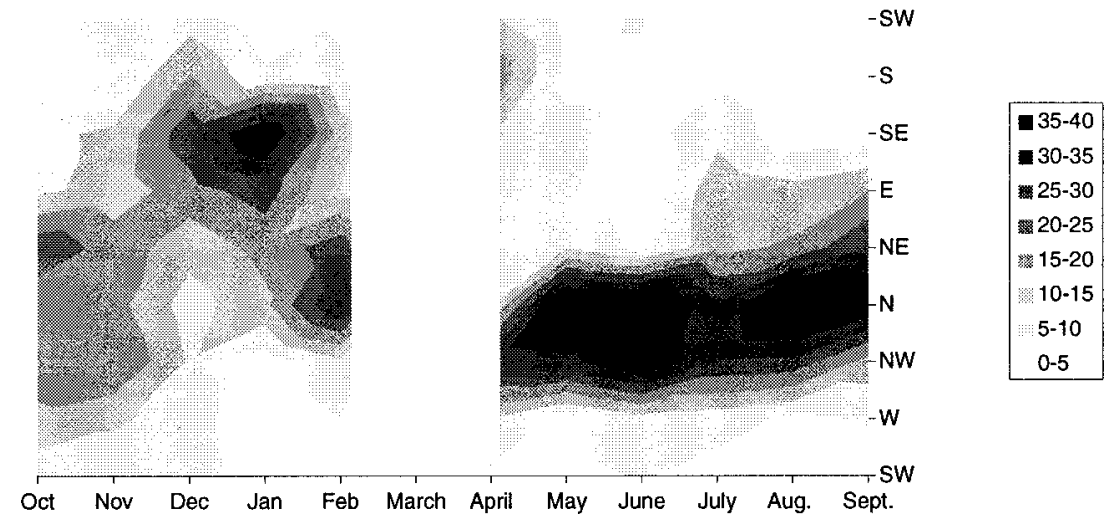

FIG. 12. Change in the prevailing wind direction through the course of the year (relative frequency). Data are missing between 23 February and 13 April 1997. direct evidence, but a net depth of $3.3 \mathrm{~m}$ must have been reached by the end of February, when the upper wind sensor was affected. We also know that snow depth had fallen back down to $3.3 \mathrm{~m}$ by midApril, when the upper wind sensor became fully operational again. A maximum depth of accumulation is estimated to have been $4.1-$ $4.3 \mathrm{~m}$, based on the ratio of Sajama monthly precipitation to that in $\mathrm{La}$ Paz and corroborated by evidence that the uppermost equipment on the station remained unburied (ra- sociated with rather dry conditions. The highest mean hourly wind speed recorded was $27 \mathrm{~m} \mathrm{~s}^{-1}$ on $10 \mathrm{June}$, and mean hourly wind speeds rose above $20 \mathrm{~m} \mathrm{~s}^{-1}$ only between May and October. During the summer months (December-February) wind speeds were much lower, averaging a surprisingly low $2.6 \mathrm{~m} \mathrm{~s}^{-1}$ for the period (Fig. 3e). Also through the summer, and extending into March on Sajama, the predominance of winds from the southeast and east provides part of the explanation for the above average precipitation (Fig. 12), as easterly winds are necessary to sustain high humidity levels in the atmosphere above the altiplano. By April winds had switched back toward the north and northwest, which remained the prevailing wind direction until August.

The daily cycle of wind speed is not very pronounced; however, the lowest wind speeds are usually recorded in the afternoon hours during the maximum expansion of the troposphere (Fig. 3e), an effect also found by P. Aceituno and A. Montecinos (1997, personal communication). Frequently, this daily cycle is suppressed by the influence of the larger-scale synoptic circulation.

\section{f. Snow accumulation (precipitation)}

Snow accumulation measurements in 1996-97 are continuous only until the end of January, at which time the snow surface under both depth sensors reached the minimum distance-to-target specified by the manufacturer $(0.4 \mathrm{~m})$. Until then, net snow accumulation was greater than $2 \mathrm{~m}$ (Fig. 13). October 1996 was dry, resulting in $14 \mathrm{~cm}$ of ablation, while two major snowfalls in November brought $32 \mathrm{~cm}$ of snow. Accumulation continued through December $(58 \mathrm{~cm})$ and January $(119 \mathrm{~cm})$. Snowfall between February and June can only be estimated based upon in- diometer, solar panel). By the end of June when the snow depth sensor heights were adjusted, net accumulation since the previous October was $\sim 2.1 \mathrm{~m}$. From July through September 1997, four snowfall events totaled $53 \mathrm{~cm}$, although there was a net surface lowering of $16 \mathrm{~cm}$, due primarily to ablation and wind scouring of the new snow.

There are important differences between the summer and winter snowfall events on Sajama, a result that will bear upon the interpretation of geochemical and isotopic variability measured in the snow and in the ice cores. Figure 14 illustrates the evolution of precipitation events typical of each season. Over 5 days, the magnitude of snowfall was equivalent $(\sim 21 \mathrm{~cm})$, which belies significant differences. The January event (thin line, Fig. 14) represents a typical summer snowfall, characterized by strong convection and moisture advection from the east. In general, these events tend to be relatively warm, with little day-today change in temperature or pressure, and with low wind speeds from the easterly direction. On the other

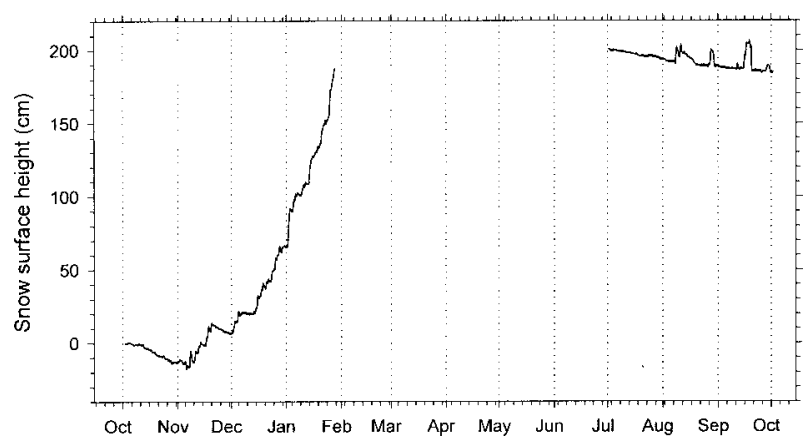

FIG. 13. Snow surface height on Sajama relative to datum of 1 October 1996, smoothed with a 13-h running average. Sensors were buried between late January and 1 July (see text). 

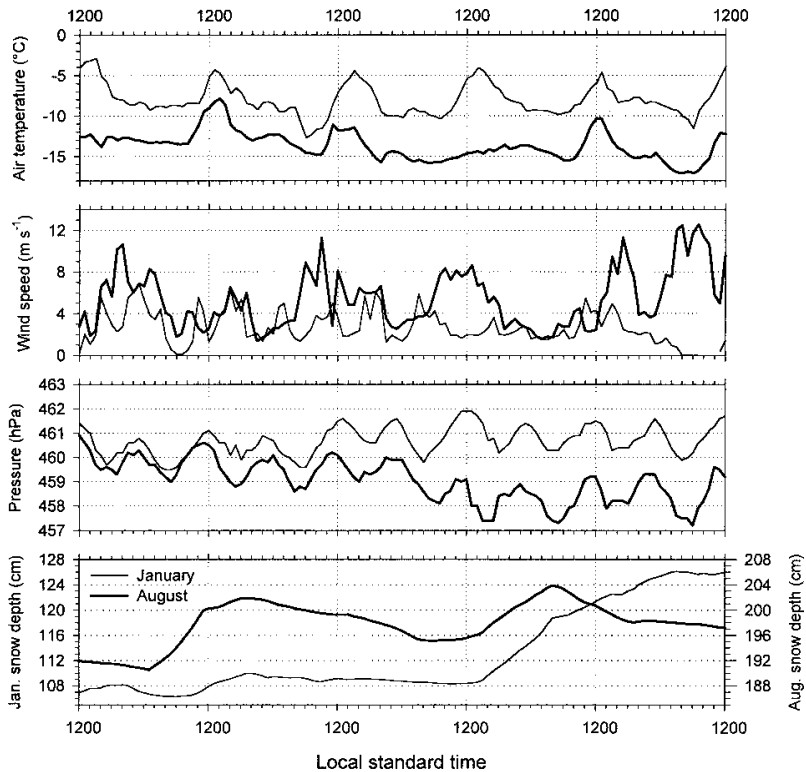

10-15 January 1997

7-12 August 1997

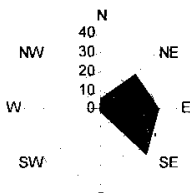

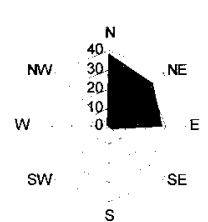

FIG. 14. Contrasting evolution of two 1997 snowfall events over 5 days (noon to noon), in summer (thin line; 10-15 January) and winter (thick line; 7-12 August). Shown from top to bottom are aspirated air temperature, wind speed, barometric pressure, snow depth above 1 October 1996 datum, and relative frequency of wind direction (indicated directions are $\pm 22.5^{\circ}$ bins).

hand, a winter snowfall as represented by the August event (thick line, Fig. 14) is related to the north- and eastward movement of a cutoff upper-air low from the extratropical circulation. Temperatures are colder (e.g., $5.7^{\circ} \mathrm{C}$ for the periods shown) and drop as the upper-level low approaches, as does station pressure. Wind speed through the August event illustrated is twice that of the January event, with winds primarily from the north. The variability of wind direction during the January and August events was similar (std dev $\left.=14^{\circ}\right)$; however, wind direction through the latter veered systematically, from north-northwest to north to east and back to north as the low progressed eastward (not shown). Through both snowfall events, Sajama measurements complement and refine the synoptic picture provided by the NCEP analyses (especially $450-\mathrm{hPa}$ geopotential heights). The station data confirm how crucial it is to analyze the climatic

pattern of single snowfall events and determine the associated stratigraphic layer within the snowpack, as geochemistry and stable isotopic composition are expected to be significantly different during these events.

\section{1996-97 Sajama observations in a longer-term context}

Measurements of precipitation and temperature at La Paz provide a longer-term perspective on the first year of data from Sajama. Observations have been made since 1898 at La Paz El Alto (4014 m, 16³1'S, $\left.68^{\circ} 11^{\prime} \mathrm{W}\right)$, located at the JFK Airport above the city of La Paz.

The period of November 1996 through March 1997 was wetter than normal on the altiplano of Bolivia. Precipitation was above the median in all five months (Fig. 15), accounting for the unexpectedly high accumulation at the Sajama station. The March total at La Paz El Alto (146 mm) was the fifth highest of the past $100 \mathrm{yr}$. Precipitation during the fall and winter was

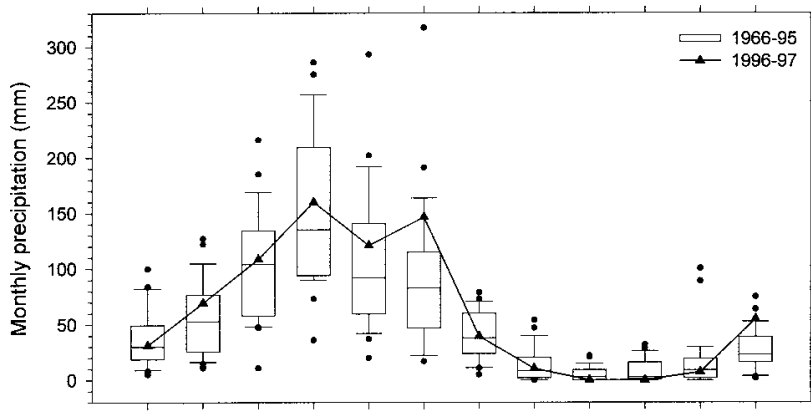

Oct-96 Nov-96 Dec-96 Jan-97 Feb-97 Mar-97 Apr-97 May-97 Jun-97 Jul-97 Aug-97 Sep-97

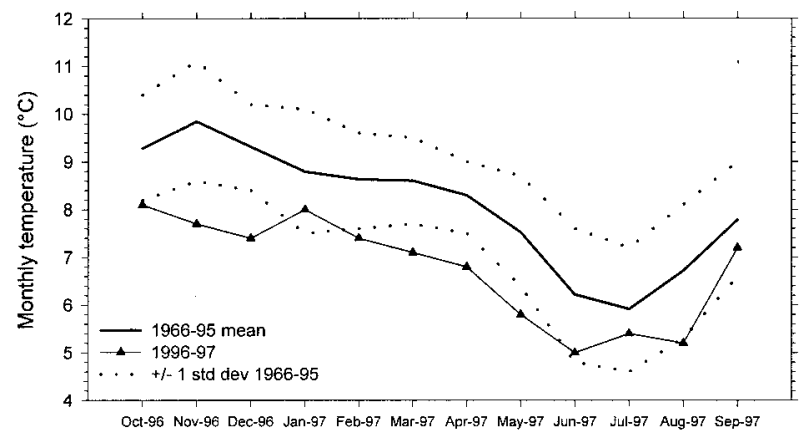

FIG. 15. Precipitation (top) and air temperature (bottom) at La Paz El Alto (4014 m, 16 $\left.{ }^{\circ} 31^{\prime} \mathrm{S}, 68^{\circ} 11^{\prime} \mathrm{W}\right)$ for October 1996 to September 1997, in a longer-term context (1996-95). Whisker plot boxes illustrate the median (line) and enclose the 25th and 75th percentiles. Error bars enclose the 10th and 90th percentiles, with extremes indicated by circles. 
normal in the context of the past $30 \mathrm{yr}$, but the total for September of 1997 was again unusually high.

The surface temperature at La Paz El Alto was more than one standard deviation below normal in all except 3 months of the period October 1996 to September 1997 (Fig. 15). The greatest departures were during December, March, and April, when mean monthly temperatures were the lowest of the period of record ( $79 \mathrm{yr})$. The first year of temperature measurement on Sajama therefore seems to reflect conditions that were well below the long-term average. Indeed, the mean station temperature for the year of $-10.7^{\circ} \mathrm{C}$ is slightly less than the $-10.3^{\circ} \mathrm{C}$ value for both the NCEP long-term mean at $450 \mathrm{hPa}$ (1985-95), and that predicted by the 10-m-depth firn temperature (V. Zagoradnov 1997, personal communication).

\section{Conclusions}

Sajama weather station measurements are helping to develop a more comprehensive view of climatic conditions at high altitudes in this remote part of the tropical Andes. The first year of measurements at the station was carried out successfully, despite $4 \mathrm{~m}$ of snow accumulation and continuously subfreezing temperature. Analysis of the observations reveals considerable variability in weather at the summit. While a clear seasonality of atmospheric processes resulting in snowfall and governing evaporation has been demonstrated, the data also illustrate that these events or intervals are more episodic in nature than previously believed. As measurements at the station continue, we will report on annual and daily cycles further in the context of synoptic-scale circulation, incorporating satellite imagery, and NCEP output.

The Sajama station provides a unique climatic database, which in conjunction with snowpack analysis will allow a more meaningful calibration of geochemical and isotopic signals in tropical ice cores. Variability of geochemical and isotopic composition, as measured within individual layers of the annual snowpack, will be related to airmass origins and transport histories as well as postdepositional influences. As the chronological and climatic significance of ice-core records are based on such variability, these associations will provide a powerful tool for interpreting tropical ice-core records.

Acknowledgments. Funding for the Sajama weather station project, and the ice core drilling, is provided by the NOAA Office of Global Programs (Paleoclimatology); the Swiss National
Science Foundation provides additional support. These agencies are gratefully acknowledged. We received enormous logistical support from B. Francou, B. Pouyaud, and the ORSTOM staff in La Paz, as well as from L.G. Thompson and his team at Ohio State University. Thanks to John Sweeney for extra effort in the machine shop. We would also like to thank Clyde Best and Dan Anderson at Campbell Scientific for their assistance.

\section{References}

Aravena, R., H. Peña, A. Grilli, O. Suzuki, and M. Mordeckai, 1989: Evolución isotopica de las Iluvias y origen de las masas de aire en el Altiplano Chileno (On the isotopic signal of rainfall in relation to the origin of air masses on the Chilean Altiplano). Isotope hydrology investigations in Latin America. IAEA-TECDOC-502, $14 \mathrm{pp}$. [Available from International Atomic Energy Agency, Vienna International Centre, Wagramerstrasse 5, A-1400 Vienna, Austria.]

Chu, P.-S., 1985: A contribution to the upper-air climatology of tropical South America. J. Climatol., 5, 403-416.

Diaz, H. F., and N. E. Graham, 1996: Recent changes in tropical freezing heights and the role of sea surface temperature. $\mathrm{Na}$ ture, 383, 152-155.

Figueroa, S. N., P. Satyamurty, and P.L. Da Silva Dias, 1995: Simulations of the summer circulation over the South American region with an Eta coordinate model. J. Atmos. Sci., 52, 1573-1584.

Francou, B., and P. Ribstein, 1995: La actual deglaciación en los Andes centrales: Un indicador del cambio climatico en curso en la alta montaña tropical (Present glacier retreat in the central Andes: An indicator of ongoing climatic change in the high mountains of the Tropics). Proc. Int. Symp. Sustainable Mountain Development, La Paz: Managing Fragile Ecosystems in the Andes, The United Nations University, 10-11.

Fuenzalida, H. P., and J. Ruttlant, 1987: Origen del vapor de agua que precipita en el Altiplano de Chile (Study on the origin of the water vapor precipitating in the Altiplano during Southern Hemisphere summer). Anales del II Congreso Interamericano de Meteorologia, Buenos Aires, Argentina, Amer. Meteor. Soc., 6.3.1.-6.3.4.

Garreaud, R. D., and J. M. Wallace, 1997: The diurnal march of convective cloudiness over the Americas. Mon. Wea. Rev., 125, 3157-3171.

Grootes, P. M., M. Stuiver, L. G. Thompson, and E. MosleyThompson, 1989: Oxygen isotope changes in tropical ice, Quelccaya, Peru. J. Geophys. Res., 94 (D1), 1187-1194.

Hastenrath, S., 1997: Annual cycle of upper-air circulation and convective activity over the tropical Americas. J. Geophys. Res., 102 (D4), 4267-4274.

— , and P. D. Kruss, 1992: The dramatic retreat of Mount Kenya's glaciers 1963-87: Greenhouse forcing. Ann. Glaciol., 16, 127-133.

Hoffmann, J. A. J., 1992: Das kontinentale Luftdruck- und Niederschlagsregime Südamerikas (The pressure- and precipitation-cycle over the South American continent). Erdkunde, 46, 40-51.

Horel, J. D., A. N. Hahmann, and J. E. Geisler, 1989: An investigation of the annual cycle of convective activity over the tropical Americas. J. Climate, 2, 1388-1403. 
Jacobeit, J., 1992: Die grossräumige Höhenströmung in der Hauptregenzeit feuchter und trockener Jahre über dem südamerikanischen Altiplano (On the large-scale upper-air flow during the main rainy season of dry and wet years on the South American Altiplano). Meteor. Z., 1 (6), 276-284.

Jordan, E., 1995: Estado actual de al glaciación en los Andes de Bolivia y Colombia. Aguas, glaciares y cambios climaticos en los Andes Tropicales (On the present state of deglaciation in the Bolivian and Columbian Andes). Proc. Seminario internacional, La Paz, Bolivia, Organisation de Recherche Scientifique et Technique d'Outre-mere, 185.

Kaser, G., and B. Noggler, 1996: Glacier fluctuations in the Ruwenzori Range (East Africa) during the 20th century-A preliminary report. Z. Gletsch. Glazial., 32, 109-117.

Lenters, J. D., and K. H. Cook, 1995: Simulation and diagnosis of the regional summertime precipitation climatology of South America. J. Climate, 8, 2988-3005.

- , and -1997 : On the origin of the Bolivian high and related circulation features of the South American climate. $J$. Atmos. Sci., 54, 656-677.

Mayewski, P. A., L. D. Meeker, S. Whitlow, M. S. Twickler, M. C. Morrison, R.B. Alley, P. Bloomfield, and K. Taylor, 1993: The atmosphere during the Younger Dryas. Science, 261, 195-197.

Mitchell, J. F. B., S. Manabe, V. Meleshko, and T. Tokioka, 1990: Equilibrium climate change and its implications for the future. Climate Change: The IPCC Assessment, J. T. Houghton, G. J. Jenkins, and J. J. Ephraums, Eds., Cambridge University Press, 131-172.

Nishizawa, T., and M. Tanaka, 1983: The annual change in the tropospheric circulation and the rainfall in South America. Arch. Meteor. Geophys. Bioclimatol., 33B, 107-116.

Nogués-Paegele, J., and K. C. Mo, 1997: Alternating wet and dry conditions over South America during summer. Mon. Wea. Rev., 125, 279-291.

Peterson, J. A., and L. F. Peterson, 1996: Ice retreat from the neoglacial maxima in the Puncak Jayakesuma area, Republic of Indonesia. Z. Gletsch. Glazial., 30, 1-9.
Ronchail, J., 1995: Interannual variability of rainfall in Bolivia. Bull. Inst. Fr. Études Andines, 24 (3), 369-378.

Rozanski, K., and L. Araguás, 1995: Spatial and temporal variability of stable isotope composition of precipitation over the South American continent. Bull. Inst. Fr. Études Andines, 24 (3), 379-390.

Schubert, C., 1992: The glaciers of the Sierra Nevada de Mérida (Venezuela): A photographic comparison of recent deglaciation. Erdkunde, 46, 58-64.

Thompson, L. G., 1995: Late Holocene ice core records of climate and environment from the tropical Andes, Peru. Bull. Inst. Fr. Études Andines, 24 (3), 619-629.

, E. Mosley-Thompson, P. M. Grootes, M. Pourchet, and S. Hastenrath, 1984: Tropical glaciers: Potential for ice core paleoclimatic reconstructions. J. Geophys. Res., 89 (D3), 4638-4646.

,-- , J. F. Bolzan, and B. R. Koci, 1985: A 1500 year record of tropical precipitation in ice cores from the Quelccaya Ice Cap, Peru. Science, 229, 971-973.

- - - M. E. Davis, N. Lin, T. Yao, M. Dyurgerov, and J. Dai, 1993: "Recent warming": Ice core evidence from tropical ice cores, with emphasis on central Asia. Global Planet. Change, 7, 145-156.

,-- , M. E. Davis, P.-N. Lin, K. A. Henderson, J. Cole-Dai, J. F. Bolzan, and K.-B. Liu, 1995: Late glacial stage and Holocene tropical ice core records from Huascarán, Peru. Science, 269, 46-50.

Virji, H., 1981: A preliminary study of summertime tropospheric circulation over South America estimated from cloud winds. Mon. Wea. Rev., 109, 599-610.

Vuille, M., and C. Ammann, 1997: Regional snowfall patterns in the high arid Andes. Climate Change, 36, 413-423.

—, D. R. Hardy, C. Braun, F. Keimig, and R. S. Bradley, 1998: Atmospheric circulation anomalies associated with 1996/97 summer precipitation events on Sajama Ice Cap, Bolivia. $J$. Geophys. Res., Atmos., 103 (D10), 11 191-11 204. 